\title{
Інгібіторна та набута форми гемофілії: погляд практикуючого лікаря
}

\author{
С.І. Горбик', П.Й. Придюк ${ }^{2}$ \\ 'Вінницький обласний діагностичний центр, Вінниця, Україна \\ Комунальне некомерційне підприємство Сумської обласної ради «Сумська обласна клінічна лікарня», Суми, Україна
}

Анотація. У статті розглянуті спільні та відмінні риси спадкової та набутої форм гемофілії з фокусом на проблему утворення інгібіторів до факторів згортання крові. Наведені власні клінічні спостереження щодо успішного лікування пацієнтів із інгібіторною формою гемофілії. Ключові слова: гемофілія, інгібіторна форма гемофілії, набута форма гемофілії.

\section{Набута і спадкова форми гемофілії: що спільне і в чому різниця?}

Класична гемофілія - спадкове X-зчеплене захворювання системи гемостазу, що характеризується зниженням або порушенням синтезу факторів згортання крові: VIII (FVIII) при гемофілії типу A, IX (FIX) - B та XI (FXI) - C. Гемофілія A та В наслідуються за рецесивним типом спадковості, пов'язаним зі статтю. Ген, який відповідає за синтез FVIII та FIX, розміщений в X-хромосомі, внаслідок чого на гемофілію хворіють виключно чоловіки. Жінки хворіють лише у випадку шлюбу між хворим на гемофілію чоловіком та жінкою-кондуктором. Гемофілія С наслідується аутосомно, хвороба не залежить від статі, трапляється досить рідко (1-2\%).

Сьогодні гемофілія А являє собою найпоширенішу та найтяжчу форму спадкових коагулопатій, яка не лише належить до складних медичних проблем, а й чинить важливий вплив на соціальний аспект, оскільки призводить до ранньої втрати працездатності та інвалідизації більшості хворих, переважно ще у дитячому віці [1]. Патологічний ген локалізується в X-хромосомі і детермінує зниження синтезу антигемофільного FVIII. Жіноча стать визначається парою XX-хромосом, чоловіча - XУ. Ген, який регулює синтез FVIII згортання крові, $\epsilon$ рецесивним і локалізується на довгому плечі Х-хромосоми. У результаті мутацій хромосоми втрачають ген, який відповідає за синтез факторів згортання крові. Хромосома, яка відповідає за гемофілію, позначається як Xh. Хворіють хлопчики, оскільки мають тільки одну X-хромосому, а жінки можуть бути тільки носіями мутантного гена (рецесивне спадкування). У чоловіків, які отримали Xh-хромосому від матері, захворювання проявляється, оскільки ні в Хh-хромосомі, ні в Ү-хромосомі немає генів, які зумовлюють синтез факторів згортання крові. Жінки, які мають Xh-хромосому та другу нормальну X-хромосому, $\epsilon$ кондукторами гемофілії, тобто самі не хворіють, але передають захворювання своїм дітям (синам), а через дочок-кондукторів можуть передавати і внукам, правнукам, тобто віддаленим поколінням. Варто зазначити, що у жінок-кондукторів активність FVIII знижена на половину, тому у них можуть виникати кровоточивість під час пологів, оперативних втручань та травмах. У жінок-гомозигот, які успадкували дві XhXh-хромосоми (від батька, хворого на гемофілію, та матері-кондуктора), виникає тяжка форма гемофілії. За правилами успадкування гена, всі дочки у хворого на гемофілію $\epsilon$ гетерозиготами і носіями гена захворювання, сини ж хворого на гемофілію можуть бути здоровими, якщо успадковують X-хромосому від здорової матері, або хворими, якщо успадковують Xh-хромосому від матері-кондуктора. Проте у $30 \%$ пацієнтів не вдається виявити сімейного анамнезу патології, тобто відмічають спорадичні випадки захворювання гемофілії (нові мутації генів).

Клінічна картина при спадковій гемофілії А супроводжу$\epsilon$ сься спонтанними тривалими кровотечами у м'язи та суглоби, при цьому тяжкість клінічного перебігу залежить від ступеня недостатності коагуляційної активності фактора згортання крові. Поява клінічної симптоматики знаходиться у лінійній залежності від ступеня дефіциту антигемофільного фактора. Так, залежно від ступеня зниження концентрації антигемофільного глобуліну в плазмі крові гемофілію прийнято класифікувати на три форми: легку, середньої тяжкості та тяжку (табл. 1). Відповідно тяжка форма гемофілії має найбільш тяжкий перебіг та характеризується спонтанними сильними кровотечами у суглоби та м'язи, що значно погіршує якість життя пацієнтів та супроводжується підвищеним ризиком смерті.

Найбільш класичним симптомом патології $\epsilon$ гемартроз скупчення крові в порожнині суглоба. У міру підвищення рухової активності дитини зростає ризик розвитку даного ускладнення.

Таблиця 1 Ступені тяжкості гемофілії залежно від активності фактора згортання

\begin{tabular}{lcl}
\hline & \multicolumn{2}{c}{ Класифікація гемофілії за ступенем тяжкості } \\
\hline \multicolumn{1}{c}{$\begin{array}{c}\text { Ступінь } \\
\text { тяжкості }\end{array}$} & $\begin{array}{c}\text { Активність } \\
\text { фактора }\end{array}$ & \multicolumn{1}{c}{ Клінічна картина } \\
\hline Тяжкий & $<1 \%$ & Спонтанні кровотечі, переважно в суглоби і м'язи \\
\hline $\begin{array}{l}\text { Середньо- } \\
\text { тяжкий }\end{array}$ & $>1-\leq 5 \%$ & $\begin{array}{l}\text { Можливі спонтанні кровотечі } \\
\text { Сильна кровотеча при травмі чи хірургічному втручанні }\end{array}$ \\
\hline Легкий & $>5-<40 \%$ & $\begin{array}{l}\text { Сильна кровотеча при серйозній травмі чи хірургічному } \\
\text { втручанні }\end{array}$ \\
\hline
\end{tabular}

Рисунок 1 Частота захворювання на НГА у популяції

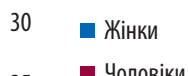

$25 \square$ Чоловіки

20

15

10

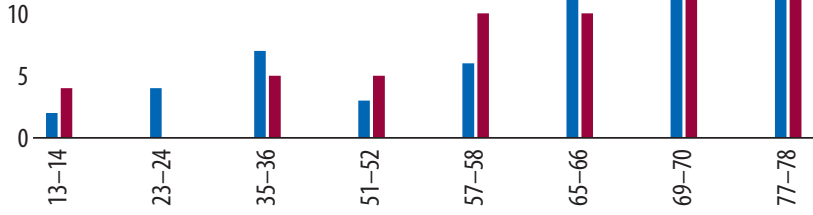

Вікові групи (років)

Рисунок 2 Зв'язування інгібітора з факторами згортання
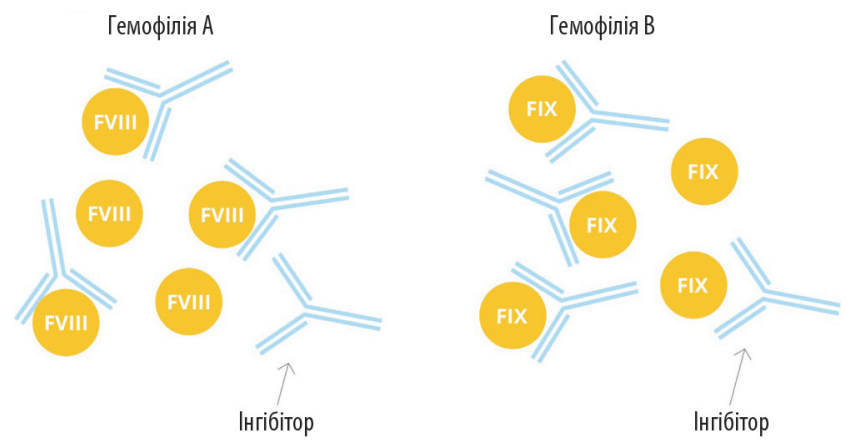
Гемартроз при гемофілії має такі особливості:

- в основному уражаються великі суглоби (колінні, ліктьові, плечові, гомілковостопні);

- частіше страждають діти старшого віку (оскільки вони більше рухаються);

- можливий спонтанний крововилив у суглоб;

- наявність місцевої симптоматики: збільшення суглоба, почервоніння, локальне підвищення температури тіла;

- набряк, обмеження рухливості, біль при русі;

- тенденція до прогресування патології з розвитком артриту, анкілозу, що стає причиною інвалідизації пацієнта.

У дітей можуть виникати життєво загрозливі крововиливи:

- ретроперитонеальні;

- внутрішньомозкові;

- заочеревинні;

- ретрофарингеальні (які призводять до асфіксії).

Крім спадкової гемофілії, в клінічній практиці відмічають набуту гемофілію (Hг) - спонтанне аутоімунне захворювання - імунокоагулопатію, що характеризується синтезом специфічних аутоантитіл до одного з власних факторів крові. На відміну від спадкової гемофілії, у переважної більшості пацієнтів НГ діагностується на пізніх етапах, зазвичай на сьомому десятку років життя, що пов'язано з рідкісною поширеністю і установкою на спадковий характер гемофілії. Аутоантитіла можуть утворюватися до різних факторів, однак найчастіше вони утворюються до FVIII — набута гемофілія А (НГА). Відомо, що захворюваність на НГА підвищується з віком, ії випадки у дітей $є$ казуїстичними. Так, згідно з останніми даними частота НГА серед дорослих становить 1,5 пацієнта на 1 млн населення на рік, у дітей віком < 16 років - 0,025 випадка на 1 млн населення на рік порівняно з 14,7 випадка у віковій категорії >85 років (рис. 1) [2]. Окрім того, на відміну від спадкової гемофілії А, яку відмічають лише у чоловіків, частота НГА практично однакова серед чоловіків і жінок. Сучасні дані свідчать, що наявний двофазний віковий розподіл захворюваності НГА: невеликий пік у жінок репродуктивного віку (20-40 років), наявність інгібітора у яких асоціюють з вагітністю; більш високий пік захворюваності серед у осіб віком >60 років.

\section{Проблема утворення інгібіторів у пацієнтів із гемофілією}

Основний принцип лікування хворих на гемофілію полягає в адекватній гемостатичній терапії із застосуванням концентратів факторів згортання крові, так звана факторна терапія. Однак незважаючи на колосальний прогрес в лікуванні гемофілії, й досі залишається актуальним питання розвитку ускладнень замісної терапії. Так, факторна терапія супроводжується ризиком розвитку інгібіторної форми гемофілії (ІФГ) — одного з найбільш серйозних ускладнень лікування гемофілії, що характеризується утворенням інгібіторного антитіла до FVIII (рідко — до FVIII та FIX), яке не дозволяє проводити адекватної факторзамісної терапії. Інгібітор при ІФГ являє собою поліклональне високоафінне lgG-антитітло, яке специфічно нейтралізує прокоагулянтну активність факторів згортання крові, що призводить до порушення процесів гемостазу. Механізм дії інгібітора полягає в тому, що антитіло прикріплюється до FVIII або FIX і нейтралізує чи пригнічує його прокоагуляційну активність, а також стимулює додаткове продукування антитіл. Як наслідок, відбувається зростання активності інгібіторних антитіл у циркулюючій крові пацієнта, що лабораторно виявляється підвищенням титру інгібіторів (рис. 2).

Сучасні дані свідчать, що інгібітори з'являються у 10-35\% хворих на гемофілію А і у 3-5\% хворих на гемофілію В. Вони виникають переважно у дитячому віці (3-6 років), надалі ймовірність розвитку інгібіторів знижується $[3,4]$. Причина розвитку інгібіторів залишається до кінця не з'ясованою, проте деякі дослідники припускають, що ІФГ може бути обумовлена існуванням генетичного поліморфізму нормального антигемофільного чинника та наявністю у хворого імунореактивної, біологічно дефектної молекули $[5,6]$. Крім того, на частоту розвитку інгібітора можуть також впливати особливості лікування. Так, дані літератури свідчать, що профілактичне лікування гемофілії асоційо- ване з нижчим ризиком розвитку ІФГ порівняно з лікуванням «за вимогою», що, ймовірно, пов'язано з меншою частотою сигналів, отриманих імунною системою.

Сьогодні відомі два типи інгібіторів до факторів згортання крові: алоантитіла (1-й тип), які утворюються у відповідь на замісну факторну терапію при спадковій гемофілії, та аутоантитіла (2-й тип), які утворюються раптово і наявні при НГА. На відміну від спадкової гемофілії, при НГА аутоантитіла являють собою поєднання поліклональних імуноглобулінів класів G1, G2 та G4, які блокують ділянки A2, A3 та С2 доменів фактора згортання, що перешкоджає активації FVIII за рахунок блокування доменів в зонах впливу FIXa, FX i FB, таким чином виключаючи його з коагуляційного каскаду. Перебіг ІФГ та НГА $є$ різним, що пов'язано 3 різною кінетикою інгібіторів (табл. 2).

При ІФГ інгібітор має пряму лінійну залежність між титром антитіл та інактивацією FVIII, і зазвичай повністю інактивує фактор згортання. Порівняно зі спадковою гемофілією, аутоантитіла при НГА не супроводжуються лінійною залежністю, тому кінетика інгібітора при НГА характеризується початковою швидкою інактивацією FVIII, після чого відмічається повільніша фаза рівноваги з частковим пригніченням активності фактора (рис. 3) [7]. Ще однією відмінністю між ІФГ та НГА $€$ те, що при спадковій гемофілії інгібітори утворюються у дитячому віці, тоді як аутоантитіла при НГА відмічаються в осіб старшої вікової групи (>60 років), які раніше не мали порушень гемостазу [8]. Так, результати одного популяційного дослідження ( $\mathrm{n=249)}$ продемонстрували, що середній вік пацієнтів з НГ становить 64 роки [9]. За результатами іншого дослідження, проведеного у Великобританії, середній вік маніфестації НГ становив 78 років [10].

\section{Таблиця 2 Відмінності між НГА та спадковою гемофілією}

\begin{tabular}{ll}
\hline \multicolumn{1}{c}{ Порівняння особливостей перебігу нгА та спадкової гемофілії } \\
\hline нгА & \multicolumn{1}{c}{ Спадкова гемофілія A } \\
\hline Більш характерна для осіб літнього віку & Більш характерна для дітей \\
\hline Жінки та чоловіки уражаються однаково & Уражаються переважно чоловіки \\
\hline Гемартрози виникають рідко & Характерні гемартрози \\
\hline Відсутнє співвідношення між титром інгібітора, & Алоантитіла інактивують FVIII \\
залишковою активністю FVIII і тяжкістю кровотеч & у прямій пропорції з їх концентрацією \\
\hline Підвищений ризик смертності & Відсутній безпосередній вплив \\
& на смертність \\
\hline
\end{tabular}

Рисунок 3 Типи інгібіторів при ІФГ та НГ [11]

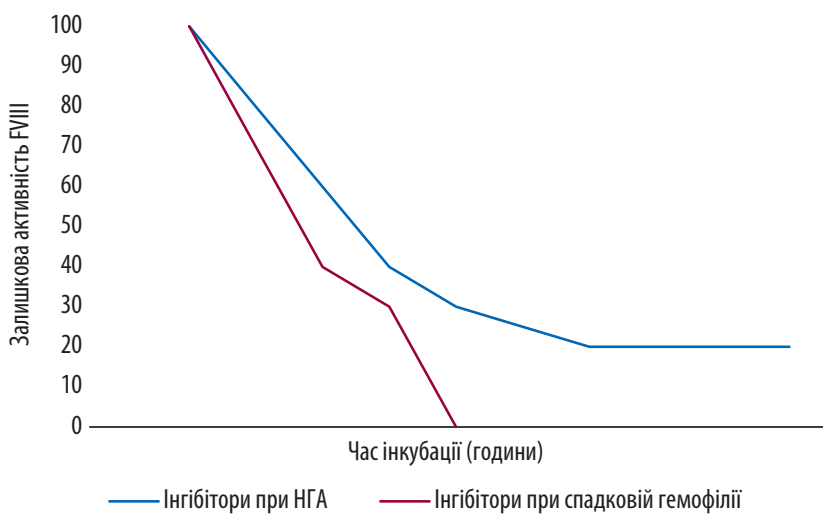

Таблиця 3 Локалізація та частота кровотеч при гемофілії [12]

\begin{tabular}{lcc}
\hline \multicolumn{2}{c}{ Кровотечі при гемофілії } \\
\hline \multicolumn{1}{c}{ Локалізація кровотечі } & Ризик для життя & Частота, \% \\
\hline Суглоби (гемартроз) & Ризик помірний & $\frac{70-80}{10-20}$ \\
\hline М'язи & & \\
\hline Слизова оболонка рота, носа та сечостатевих шляхів & & $<5$ \\
\hline Внутрішньочерепна & Загрожує життю & \\
\hline Шия/горло & &
\end{tabular}




\section{Як клінічно запідозрити розвиток інгібіторів при гемофілії?}

Ключовими симптомами при ІФГ, що свідчать про розвиток інгібітора до фактора згортання крові, $\epsilon$ наявність безконтрольних кровотеч та відсутність відповіді на введення звичайної дози концентратів факторів згортання. Інгібітор зазвичай діагностують, коли хворий або члени його сім'ї помічають, що гемостатична терапія стає менш ефективною, ніж зазвичай. Також наявність інгібітора може бути запідозрена, якщо на тлі адекватного лікування кровотеча не зупиняється у визначені терміни.

Ознаки і симптоми розвитку ІФГ:

- після введення звичайної дози концентратів фактора згортання крові кровотеча не зупиняється одразу;

- призначене відповідно до протоколів лікування стає все менш ефективним;

- кровотеча все тяжче зупиняється.

Клінічно ІФГ проявляється відсутністю або недостатністю гемостатичної відповіді на лікування препаратами факторів згортання крові, які застосовують в рекомендованих протоколами з лікування гемофілії дозах, що ускладнює тяжкість клінічного перебігу гемофілії, кровотечі набувають неконтрольованого характеру, що може стати серйозною проблемою як для лікаря, так і для самого пацієнта, оскільки асоційоване з ризиками розвитку тяжких кровотеч та крововиливів, що виникають спонтанно чи внаслідок травм, а ступінь їх тяжкості корелює зі ступенем концентрації фактора (табл. 3). Найбільш характерним та специфічним симптомом гемофілії $\epsilon$ гемартрози - крововиливи у великі суглоби (гомілковостопні, колінні, кульшові, плечові, ліктьові). Відомо, що гемартрози підвищують ризик розвитку прогресуючого захворювання суглобів - гемофілічної артропатії, що впливає на якість життя пацієнтів та може призводити до інвалідизації та потреби у спеціалізованих пристроях, що полегшують мобільність пацієнтів.

На відміну від спадкової гемофілії А, діагноз НГА повинен бути запідозрений у осіб з аномальною кровотечею чи подовженим активованим частковим протромбіновим часом (АЧТЧ) за умови відсутності особистого/сімейного анамнезу розладів згортання крові. При НГА клінічно тяжкість кровотечі не співвідносна з рівнем FVIII чи титром інгібітора, а гемартрози виникають вкрай рідко. Клінічна картина при НГА зазвичай характеризується розвитком спонтанних тяжких кровотеч у шкіру, м'язи, м'які тканини та слизову оболонку. При цьому ступінь тяжкості кровотеч може бути значно вищим, ніж у хворих зі спадковою гемофілією. Найбільш частими станами, які призводять до розвитку НГА, $\epsilon$ аутоімунні злоякісні захворювання та вагітність. Так, дані літератури свідчать, що вагітність та пологи $\epsilon$ однією з найбільш поширених причин розвитку НГА серед жінок репродуктивного віку, частота якої становить близько 18\% [13]. При цьому вищому ризику піддаються жінки з першою вагітністю. Патогенез розвитку післяпологової НГА не визначений, однак деякі автори припускають, що пусковим моментом у розвитку НГА у період вагітності $\epsilon$ сенсибілізація жінки фетальним FVIII у цей час [14]. Найбільш тяжкими проявами НГА в цьому випадку $є$ масивні післяпологові кровотечі, відстрочені маткові кровотечі, що виникають на 3-150-й день [15].

Захворювання та стани, які можуть призвести до розвитку НГ:

- вагітність та пологи;

- аутоімунні захворювання;

- солідні пухлини;

- гематологічні пухлини;

- запальні та інфекційні захворювання;

- прийом лікарських препаратів (пеніцилін, сульфаніламіди, хлорамфенікол та ін.).

На відміну від ІФГ, при якій відмічають крововилив в м'язи та суглоби, для хворих з набутою гемофілією більш характерною $\epsilon$ поява спонтанних великих гематом, тяжкої гематурії, ретрофарингеальних і ретроперитонеальних гематом та крововиливів в головний мозок [16]. Кровотечі часто бувають масивними, небезпечними для життя. Статистичні дані останніх років свід- чать, що смертність від кровотеч при НГА коливається в межах 7,9-22\%, з найвищим ризиком в перші тижні після маніфесту захворювання. Так, за даними реєстру ЕАCH2, більше 70\% епізодів кровотеч оцінюються як тяжкі [17]. Результати іншого дослідження продемонстрували, що у більше ніж 97\% пацієнтів з НГ відмічають загрозливі для життя кровотечі [18].

Таким чином, розвиток інгібіторів при спадковій та набутій гемофілії - тяжкий клінічний стан, і недостатня обізнаність медичного персоналу може призвести до затримки діагностики та/ або призначення неадекватної терапії, що в майбутньому призведе до високої захворюваності та смертності пацієнтів. Відповідно, здійснення адекватного менеджменту пацієнта $\epsilon$ вкрай важливим фактором, який визначає подальший прогноз захворювання.

\section{Стратегії діагностики \\ діагностики інгібіторів}

Відповідно до сучасних рекомендацій першочерговим пунктом менеджменту пацієнтів з ІФГ $\epsilon$ виявлення інгібітора. Після підозри на розвиток інгібітора необхідним $\epsilon$ проведення специфічного тесту Бетезда чи його модифікації Неймегена, який вимірює активність інгібіторів, виявлених у плазмі крові, та виража$\epsilon$ ться в одиницях Бетезда (БО/мл) або титрі Бетезда. За 1 одиницю інгібітора (БО) приймають таку кількість інгібітора, яка інактивує

Таблиця 4 Розподіл пацієнтів із наявністю інгібітора залежно від титру

\begin{tabular}{|c|c|}
\hline \multicolumn{2}{|r|}{ Розподіл пацієнтів залежно від титру інгібітора } \\
\hline $\begin{array}{c}\text { Титр інгібітора, } \\
\text { Б0/мл }\end{array}$ & Інтерпретація \\
\hline$<0,6$ & Не виявлено \\
\hline $0,6-<5$ & $\begin{array}{l}\text { Низький титр/низькореагуючий інгібітор: } \\
\text { • можна подолати додатковим введенням FVIII } \\
\text { • відсутнє значне підвищення інгібітора після декількох днів } \\
\text { введення препарату } \\
\text { • іноді минає самостійно }\end{array}$ \\
\hline$\geq 5$ & $\begin{array}{l}\text { Високий титр/високореагуючий інгібітор: } \\
\text { • FVIII неефективний } \\
\text { • швидке підвищення титру інгібітора після введення фактора } \\
\text { • титр може знизитися, якщо пацієнт протягом тривалого часу } \\
\text { не буде мати впливу FVIII }\end{array}$ \\
\hline
\end{tabular}

Рисунок 4 Алгоритм діагностики НГ

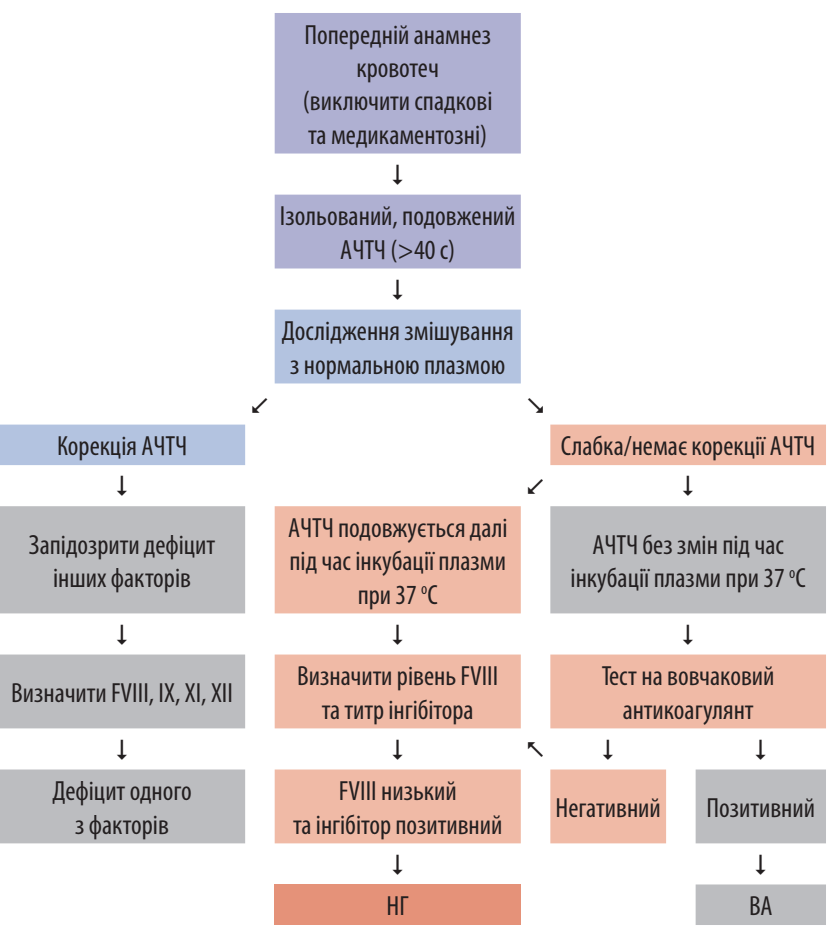


50\% доданого FVIII або FIX в 1 мл плазми крові. Для верифікації інгібітора необхідне його повторне визначення з інтервалом в 1 тиж, позитивним вважають результат >0,6 БО. При ІФГ, залежно від титру інгібітора, виокремлюють осіб з низьким титром/ низькореагуючим (0,6-<5 БО/мл) та високим титром/високореагуючим інгібітором ( $\geq 5$ БО/мл) (табл. 4). На сьогодні відомо, що ризик розвитку інгібітора зворотно пропорційний тривалості замісної терапії. Так, для пацієнтів, які раніше ніколи не отримували препарат фактора FVIII/FIX, ризик розвитку інгібітора становить 30\% у перші 20 днів експозиції (ДЕ), тоді як у пацієнтів, яким хоча 61 раз вводився фактор, - <10\% у перші $20-50,3-5 \%-$ 50-150 та 0,3\% — >150 ДЕ [19]. Раннє визначення інгібітора $\epsilon$ важливим для спроби проведення ерадикації інгібітора та уникнення невідкладної ініціації індукції імунної толерантності (IIT).

Рекомендації щодо проведення раннього тестування на наявність інгібітора:

- дорослим особам із >150 ДЕ;

- при відсутності відповіді на замісну факторну терапію;

- після оперативних втручань;

- після інтенсивного лікування;

- у дітей інгібітор слід перевіряти через кожні 5 днів до 20-го, кожні 10 між 2-м та 50-м ДЕ та $\geq 2$ разів на рік до 150 ДЕ.

Тестування на інгібітор $є$ обов'язковим:

- перед плановими інвазивними процедурами;

- коли клінічна або лабораторна відповідь на застосування концентрату нижче оптимальної;

- до та після заміни препарату;

- через 2-3 тиж після інтенсивного лікування;

- $\geq 5$ ДЕ чи оперативні втручання;

- у післяопераційний період у разі виникнення клінічно обґрунтованої підозри.

Як відомо, при НГА кровотечі мають масивний небезпечний для життя перебіг, тому час до встановлення діагнозу та призначення лікування $\epsilon$ критичним [20]. Діагноз повинен бути запідозрений у осіб з аномальною кровотечею за умови відсутності особистого/сімейного анамнезу розладів згортання крові, після чого необхідним буде проведення подальшого обстеження пацієнта (рис. 4). Перший етап діагностики НГА полягає у проведенні гемостазіологічного скринінгу: підрахунку кількості тромбоцитів, визначення часу кровотечі, АЧТЧ, протромбінового часу (ПЧ), тромбінового часу (ТЧ) і фібриногену. Основними діагностичними критеріями НГА $\epsilon$ ізольоване збільшення АЧТЧ при нормальних показниках ПЧ, ТЧ, концентрації фібриногену, фактора Віллебранда, кількості тромбоцитів та їх агрегаційної здатності при відсутності вовчакового антикоагулянта (ВА). Важливо зазначити, що визначення АЧТЧ $\epsilon$ доцільним у пацієнтів, що не мають супутніх хронічних хвороб, які можуть впливати на результати коагуляційних тестів, або потребують лікування антикоагулянтами, оскільки в таких випадках можливе підвищення не лише АЧТЧ, а й інших показників (ПЧ, ТЧ та час кровотечі).

Найбільш простим способом диференційної діагностики між наявністю інгібітора й ізольованим дефіцитом факторів згортання $\epsilon$ проведення тесту корекції (мікс-тест), суть якого полягає в змішуванні плазми крові пацієнта з нормальною плазмою у співвідношенні 1:1 і подальшій повторній оцінці АЧТЧ. Результати мікс-тесту демонструють, що у разі відсутності в крові хворого інгібітора відбувається корекція показника АЧТЧ до нормальних значень, якщо ж інгібітор наявний, то корекції АЧТЧ не відбувається. Так як інгібітор сам по собі $\epsilon$ «повільним» антитілом, інгібування фактора в звичайних умовах не може відбуватися негайно, в зв'язку з чим оцінка АЧТЧ проводиться безпосередньо відразу і через 2 год після змішування [21]. При отриманні позитивного результату мікстесту з метою остаточного підтвердження діагнозу НГА проводиться визначення титру інгібітора методом Бетезда та/або імуноферментним аналізом, останній базується на специфічній реакції антиген-антитіло, однак даний метод широкого застосування в клінічній практиці не отримав, оскільки визна- чає лише наявність/відсутність антитіл та не надає інформації щодо інгібіторної активності. Таким чином, діагноз НГА підтверджується у разі зниження рівня FVIII та наявності інгібіторів FVIII [22].

Далі наведено власний досвід Вінницької обласної дитячої клінічної лікарні щодо менеджменту педіатричних пацієнтів із ІФГ.

\section{Клінічний випадок}

Хворий Х., 12 років. 3 дитинства спостерігається та лікується у Вінницькій обласній дитячій клінічній лікарні з діагнозом «Гемофілія А». У 2011 р. звернувся для надання медичної допомоги з приводу масивних підшкірних гематом по всьому тілу. Під час лікування на 5-ту добу введення препаратів FVIII (кріопреципітат) покращання стану не відмічено, з'явилися ознаки резистентності до замісної трансфузійної терапії.

При огляді показники життєдіяльності без особливих змін. Шкіра бліда, масивні підшкірні гематоми по всьому тілу синьобагряного кольору. Періодично мати відмічала носові кровотечі та довготривалі кровотечі в місцях ін'єкцій після забору крові.

Дані лабораторних обстежень при госпіталізації:

1. Загальний аналіз крові: гемоглобін - 129 г/л, еритроцити $-4,0 \cdot 10^{12} /$ л, лейкоцити $-6,1 \cdot 10^{9} /$ л, швидкість осідання еритроцитів - 10 мм/год, тромбоцити - 326 $10^{9} /$ л.

2. Коагулограма: вміст FVIII <1\%, рівень інгібіторних антитіл до FVIII - 7,6 БО/мл, активності ВА не виявлено.

На основі отриманих даних діагностовано гемофілію А з інгібітором у високому титрі, спонтанні підшкірні гематоми тулуба.

Проведено лікування активованим концентратом протромбінового комплексу (АКПК) в дозі по 200 ОД/кг маси тіла на добу внутрішньовенно. Лікування проводили протягом 10 днів, стан хворого покращився, гематоми зникли. Через відсутність плазмового препарату FVIII в достатній кількості для проведення IIT хворий переведений на профілактичне лікування препаратом АКПК по 500 ОД 1 раз на добу 2 рази на тиждень постійно. Пацієнт отримував профілактику декілька років, що допомогло уникнути великих кровотеч. Стан хворого був стабільним і з немедичних причин профілактичне лікування було припинено.

На жаль, в минулі роки державне забезпечення пацієнтів препаратами для профілактичного лікування при гемофілії А було недостатнім. Щоб досягти хоча би мінімального терапевтичного ефекту профілактичного лікування, призначено дозування та кратність введення, виходячи з наявної кількості препарату, зокрема АКПК. Варто зазначити, що, згідно з інструкцією для застосування АКПК, при профілактиці гемофілії А з наявністю інгібітору доза становить 70-100 ОД/кг/добу через день. Таким чином, рекомендована добова профілактична доза для дитини масою тіла 30 кг повинна становити від 2000 ОД на добу через день. Як зазначено вище, пацієнтам 3 наявністю інгібіторів, за умов достатнього фінансування і забезпеченості препаратом FVIII рекомендовано проведення IIT, що в умовах сучасності $\epsilon$ можливим в Україні. Ретроспективно аналізуючи цей випадок, відповідно до сучасних знань і протоколів лікування такі пацієнти мають отримувати IIT під прикриттям від проривних кровотеч за допомогою АКПК.

За підтримки ТОВ «Такеда Україна» VV-MEDMAT-47900

\section{Список використаної літератури/References:}

1. Averyanov E.V., Semenyaka V.I., Rybakov A.R. (2015) Study of the efficacy of BioClot A in patients with hemophilia A with hemarthrosis of large joints. Hematology. Transfusiology. Eastern Europe, 3: 105-111. (In Rus.).

2. Collins P., Baudo F., Huth-Kühne A. et al. (2010) Consensus recommendations for the diagnosis and treatment of acquired hemophilia A. BMC Res. Notes, Jun. 7.

3. Collins P.W., Hirsch S., Baglin T. et al. (2007) Acquired haemophilia A in the United Kingdom: a 2-year national surveillance study by the United Kingdom Haemophilia Centre Doctors' Organistaion. Blood, 109(5): 1870-7. 
4. Teitel J., Berntorp E., Collins P. et al. (2007) A systematic approach to controlling problem bleeds in patients with severe congenital haemophilia $A$ and high-titre inhibitors. Haemophilia, 13(3): 256-263.

5. Wight J., Paisley S. (2003) The epidemiology of inhibitors in haemophilia A: a systematic review. Haemophilia, 9(4): 418-435.

6. Vydyborets S.V.,Derpak Yu.Yu., PopovichYu.Yu. (2018) Hemophilia. Fam. Med., 6(80):61-66. (InUkr.).

7. DiMichele D. M., Hoots W. K., Pipe S. W. et al. (2007) International workshop on immune tolerance induction: consensus recommendations. Haemophilia, 13(1): 1-22. doi: 10.1111/j.1365-2516.2007.01497.x.

8. Astermark J. (2015) FVIII inhibitors: pathogenesis and avoidance. Blood; 125(13): 2045-2051. doi: 10.1182/blood-2014-08-535328.

9. Yee T.T., Taher A., Pasi K.J. et al. (2000) A survey of patients with acquired haemophilia in a haemophilia centre over a 28-year period. Clin. Lab. Haematol., 22(5): 275-278.

10. Collins P.W., Hirsch S., Baglin T. et al. (2007) Acquired haemophilia A in the United Kingdom: a 2-year national surveillance study by the United Kingdom Haemophilia Centre Doctors' Organistaion. Blood, 109(5): 1870-1877.

11. Ma A.D., Carrizosa D. (2006) Acquired factor VIII inhibitors: pathophysiology and treatment. Hematology Am. Soc. Hematol. Educ. Program, 432-437.

12. Srivastava A., Santagostino E., Dougall A. et al. (2020) WFH Guidelines for the Management of Hemophilia, 3rd edition. Haemophilia, 26(6): 1-158. doi: 10.1111/hae.14046.

13. Huth-Kühne A., Baudo F., Collins P. et al. (2009) International recommendations on the diagnosis and treatment of patients with acquired haemophilia. Haematologica, 94(4): 566-575.

14. Barlamov P.N., Shchekotov V.V.1, Shutylev A.A. et al. (2015) Postpartum acquired hemophilia. Klin. Med., 93(10): 67-71. (in Rus.).

15. Svirin P.V., Larina L.E. (2009) Acquired hemophilia. Med. Council, 4: 57-61. (In Rus.).

16. Knoebl P., Marco P., Baudo F. et al. (2012) Demographic and clinical data in acquired hemophilia A: results from the European Acquired Haemophilia Registry (EACH2). J. Thromb. Haemost., 10(4): 622-631. doi: 10.1111/j.1538-7836.2012.04654.X.
17. Baudo F., Collins P., Huth-Kühne A. et al. (2012) Management of bleeding in acquired hemophilia A: results from the European Acquired Haemophilia (EACH2) Registry. Blood, 120(1): 39-46. doi: 10.1182/blood-2012-02-408930.

18. Zeitler H., Ulrich-Merzenich G., Goldmann G. et al. (2010) The relevance of the bleeding severity in the treatment of acquired haemophilia - an update of a single-centre experience with 67 patients. Haemophilia, 16(102): 95-101. doi: 10.1111/j.1365-2516.2008.01922.x.

19. Wight J., Paisley S. (2003) The epidemiology of inhibitors in haemophilia A: a systematic review. Haemophilia, 9: 418-435.

20. Pardos-Gea J., Fernández-Díaz N., Parra R. et al. (2018) Diagnostic delay in acquired haemophilia: Analysis of causes and consequences in a 20-year Spanish cohort. Haemophilia, 24(3): e163-e166.

21. Wagenman B.L., Townsend K.T., Mathew P. et al. (2009) The laboratory approach to inherited and acquired coagulation factor deficiencies. Clin. Lab. Med., 29: 229-252.

22. Tiede A., Collins P., Knoebl P. et al. (2020) International recommendations on the diagnosis and treatment of acquired hemophilia A. Haematologica, 105(7): 1791-1801.

\section{Inhibitory and acquired hemophilia: the view of the practitioner}

\section{S.I. Gorbyk ${ }^{1}$, P.Y. Prydyuk ${ }^{2}$}

'Vinnytsia Regional Diagnostic Center, Vinnytsia, Ukraine ${ }^{2}$ Municipal Non-Profit Enterprise of Sumy Regional Council «Sumy Regional Clinical Hospital», Sumy, Ukraine

Abstract. The article considers the common and distinctive features of hereditary and acquired hemophilia with a focus on the problem of formation of inhibitors to coagulation factors. Own clinical observations on the successful treatment of patients with inhibitory hemophilia are presented.

Key words: hemophilia, inhibitory hemophilia, acquired hemophilia.

\author{
Information about the author: \\ Gorbyk Svitlana I. — pediatric hematologist, Vinnytsia Regional Diagnostic Center, Center \\ B, Vinnytsia, Ukraine. \\ Prydyuk Pavlo Y. - Head of Hematology Department of the Municipal Non-Profit Enter- \\ prise of Sumy Regional Council « Sumy Regional Clinical Hospital», Doctor of the highest \\ category, Hematology Expert at the Department of Health in Sumy Region, Member of the \\ European Hematology Association (ENA), Sumy, Ukraine. \\ Address for correspondence: \\ Svitlana Gorbyk \\ 21018, Vinnytsia, Malinovsky st., 11 \\ E-mail: sgorbik1973@gmail.com
}

